\title{
THE THERAPEUTIC EFFECT OF CHANGYUNING GRANULES COMBINED WITH RETENTION ENEMA ON ALLEVIATING THE SYMPTOMS OF ULCERATIVE COLITIS
}

\author{
YUNLANG NA ${ }^{1}$, JINKUN ZHAO $^{1}$, ZHENYU SU ${ }^{1}$, YAN JIAO ${ }^{2 *}$ \\ ${ }^{1}$ Harbin Hospital of Traditional Chinese Medicine, Harbin, 150000, China \\ ${ }^{2}$ The People's Hospital of Dazu, Chongqing, 402360, China \\ *corresponding author: jiaoyandazu@163.com
}

Manuscript received: November 2020

\begin{abstract}
Ulcerative colitis (UC) is an inflammatory bowel disease that lacks an effective treatment without severe side effects. In this study, we aimed to evaluate the clinical efficacy of Changyuning granules (CYNG) combined with retention enema on patients with ulcerative colitis (UC) evaluating the effects on the intestinal mucosa of patients. Ninety-six patients with UC were randomly divided into observation group and control group (48 cases in each group). Patients in the control group were treated for 12 weeks with Kuiyangling enema, and the observation group was treated with CYNG plus Kuiyangling enema. Both types of treatment can improve the main clinical symptoms such as diarrhoea, bloody purulent stool, abdominal pain, the effects being superior after CYNG treatment. The total effective rate of the observation group is higher than that of the control group. The treatment with CYNG plus Kuiyangling enema is superior to the treatment with Kuiyangling enema in reducing intestinal mucosal lesions, inhibiting the expression of TLR4, reducing inflammation, promoting the recovery of intestinal mucosal function, and improving the immune function of patients. In conclusion, CYNG combined with Kuiyangling enema has a good clinical effect in the treatment of UC, which can significantly improve intestinal mucosal inflammation, promote the recovery of intestinal mucosal function, and improve the immune function of patients with minimum side effects.
\end{abstract}

\section{Rezumat}

Colita ulcerativă (UC) este o boală inflamatorie intestinală care nu beneficiază de un tratament eficient, fără efecte secundare severe. În acest studiu, ne-am propus să evaluăm eficacitatea clinică a granulelor Changyuning (CYNG) combinate cu clisma de retenție la pacienții cu UC, evaluând efectele asupra mucoasei intestinale a pacienților. Nouăzeci și șase de pacienți cu UC au fost împărțiți aleatoriu în grupul de studiu și grupul control (48 de cazuri în fiecare grup). Pacienții din grupul control au fost tratați timp de 12 săptămâni cu clismă Kuiyangling, iar grupul de studiu a fost tratat cu CYNG, pe lângă clisma Kuiyangling. Ambele tipuri de tratament pot ameliora principalele simptome clinice precum diaree, scaun purulent sângeros, dureri abdominale, efectele înregistrate fiind superioare după tratamentul cu CYNG. Tratamentul cu clisma Kuiyangling plus CYNG a fost superior tratamentului cu clisma Kuiyangling în reducerea leziunilor mucoasei intestinale, inhibarea expresiei TLR4, reducerea inflamației, promovarea recuperării funcției mucoasei intestinale și îmbunătătirea funcției imune a pacienților.

Keywords: ulcerative colitis, CYNG, retention enema, intestinal mucosa

\section{Introduction}

Ulcerative colitis (UC) is an inflammatory disease of the intestine with a not very clear cause [1]. Currently, it is considered that immune, environmental, genetic, and other factors are implicated in its pathogenesis [2]. Under pathological conditions, the intestinal wall is highly sensitive to microorganisms in the intestinal cavity, causing a series of local immune responses involving a variety of active immune cells [3]. The immune cells secrete various cytokines, including inflammatory factors and inflammatory inhibitors. Inflammatory factors drive many neutrophils, lymphocytes, and macrophages to accumulate in the intestine, producing many tissue degrading enzymes and cytotoxic oxygen metabolites, thus causing inflammation, erosion, and ulcers of the intestinal mucosa $[4,5]$. Inflammation and consequent damage is reduced by anti-inflammatory agents via inhibition of immune cells response [6]. Therefore, a variety of cytokines secreted by active immune cells play an important regulatory role in the onset and development of intestinal inflammation. An effective treatment is missing from the clinic and the current pharmacological options depend on the severity of the disease. Pharmacological options as glucocorticoids, sulfasalazine, 5-aminosalicylates, calcineurin inhibitors and biological agents can alleviate the symptoms to some extent but with a lot of side effects [7]. 
FARMACIA, 2021, Vol. 69, 4

Nowadays, a lot of research is focused on the identification of plant extracts with beneficial therapeutical effects in ulcerative colitis and fewer side effects [8-11]. Traditional Chinese Medicine (TCM) is used for a long time in Asia to alleviate different pathologies along with traditional allopathic treatment. In the last years, many TCM formulations have been evaluated for their beneficial effects in ulcerative colitis with promising results $[12,13]$ In this study, we aimed to evaluate the clinical efficacy of Changyuning granules (CYNG) combined with retention enema for the treatment of patients with UC.

\section{Materials and Methods}

\section{Pathological data}

The outpatients and inpatients of the anorectal department of the Harbin Hospital of traditional Chinese Medicine, China from April 2018 to May 2020 were selected during the UC active period. There were included 96 patients with spleen and stomach qi deficiency, damp-heat accumulation and blood stasis according to the criteria of traditional Chinese medicine. Their clinical manifestations included abdominal pain, diarrhoea, bloody mucopurulent stool, tenesmus, constipation, fatigue, yellowish fur, slippery and rapid pulse. The age of the patients included in the study was between 22 and 68 years old, with no gender limitation. Each patient included in the study signed an informed consent for participation. The clinical study was approved by the Ethical Committee of Harbin Hospital of traditional Chinese Medicine, China. The patients were randomly divided into an observation group and a control group with 48 cases each. In the observation group, there were 26 males and 22 females with an average age of (39.2 \pm 8.5$)$ years old and an average course of disease of $(4.20 \pm 1.25)$ years. In the control group, there were 25 males and 23 females with an average age of $(38.5 \pm 9.6)$ years old and an average course of disease of $(4.36 \pm 1.52)$ years. There were no obvious complications in the two groups. There was no statistically significant difference in data between the two groups $(\mathrm{p}>0.05)$.

\section{Treatment}

In the control group, the patients received Kuiyangling enema used in TCM for the treatment of UC. Kuiyangling formulation contains: $30 \mathrm{~g}$ Kushen (Sophora flavescens, Fabaceae family) (Hubei Tianji Pharmaceutical Co. Ltd., China), 10 g Sanqi (Panax notoginseng (Burkill) F.H. Chen ex C.H., Araliaceae family) (Hubei Tianji Pharmaceutical Co. Ltd., China), 15 g Baiji (Rhizoma of Bletilla stiata, Orchidaceae Family) (Hubei Tianji Pharmaceutical Co. Ltd., China), $15 \mathrm{~g}$ Ercha (Catechu) (Hubei Tianji Pharmaceutical Co. Ltd., China), 10 g Qingdai (Indigo Naturalis) (Hubei Tianji Pharmaceutical Co. Ltd., China), 15 g Puhuang
(Typhae Pollen) (Hubei Tianji Pharmaceutical Co. Ltd., China), 15 g Huaihua (Sophorae Flos, Sophora japonica, Leguminosae family) (Hubei Tianji Pharmaceutical Co. Ltd., China), $10 \mathrm{~g}$ Wubeizi (Galla Chinensis is the gall caused by the Schlechtendalia chinensis on the leaves of Rhus chinensis, Anacardiaceae Family) (Hubei Tianji Pharmaceutical Co. Ltd., China). One dose of $10 \mathrm{~g}$ was used for decoction in water to obtain $100 \mathrm{~mL}$ decoction and administered as an enema after defecation once per day for 12 weeks. The patients in the observation group received the same treatment as the control group plus $10 \mathrm{~g}$ of CYNG twice a day orally for 12 weeks. The composition of CYNG includes Huanglian (Coptidis rhizoma, rhizome of Coptis chinensis Franch., $C$. deltoidea C.Y. Cheng et Hsiao or C. teeta Wall., Ranunculaceae family) $6 \mathrm{~g}$, Jiao Bai Zhu (deep-fried Atractylodes macrocephala Koidz., Asteraceae family) $10 \mathrm{~g}$, Baitouweng (Pulsatillae radix, radix of Pulsatilla chinensis (Bge.) Regel, Ranunculaceae family) 10 g, Machixian (Portulacae herba, herba of Portulaca oleracea L., Portulacaceae family) 10 g, Huangbai (cortex of Phellodendron amurense, Rutaceae family) $6 \mathrm{~g}$, and Huangqin (Scutellariae radix, the radix of Scutellaria baicalensis Georgi, Lamiaceae family) $10 \mathrm{~g}$.

After the treatment, the relevant symptoms and signs of the patients were observed and recorded. The colonoscopy was performed and tissue samples were collected before treatment and after 12 weeks of treatment.

Specimen collection

Colonoscopy was performed before and after the treatment using a video colonoscope (Jiangsu Joymed Tech Co., Ltd., China). Three tissue specimens were taken from each lesion site. The biopsy specimens were fixed with $4 \%$ formaldehyde solution and were embedded with paraffin. There were carried out serial sections of $3 \mu \mathrm{m}$, and haematoxylin-eosin staining was performed along with immunohistochemistry studies. Serum inflammatory factors

Before and at the end of the 12 weeks of treatment, $3 \mathrm{~mL}$ of venous blood was collected. The serum was separated at $3000 \mathrm{rpm}$. The enzyme-linked immunosorbent assay (ELISA) kits from Thermo Fisher, USA were used to determine interleukin (IL)-1 $\beta$, matrix metalloproteinase (MMP)-1 and tumour necrosis factor (TNF)- $\alpha$ level according to the manufacturer instructions.

Immune function

Before treatment and at the end of the 12 weeks of treatment, $3 \mathrm{~mL}$ peripheral venous blood was collected and it was placed in an EDTA anticoagulation tube, and $10 \mu \mathrm{L}$ antibodies (including CD3+, CD4+ and $\mathrm{CD} 8+$ ) were added to it to determine the changes in $\mathrm{T}$ lymphocyte subsets. The flow cytometry and matching kits from the BD, USA were used for the determination according to the manufacturer instructions. 


\section{Intestinal mucosal function}

Before treatment and at the end of the 12 weeks of treatment, $5 \mathrm{~mL}$ fasting venous blood was collected and centrifuged. The serum D-lactic acid level and diamine oxidase (DAO) activity in the two groups were determined by enzymatic spectrophotometry using a commercial kit according to the manufacturer instructions (Jiancheng Bioengineering Institute of Nanjing, China).

Reverse transcription PCR (RT-PCR) detection of TLR4 (Toll Like Receptor 4) expression in tissue samples

RNA was extracted from $1 \mathrm{~g}$ tissues, and a small amount of RNA was used for colorimetric concentration determination and integrity identification. PCR primers were designed using Primer Premier 5.0 software (PREMIER Biosoft International, USA), and the primer sequence was: $\beta$-actin: F: GAAATCGTGCGTGACATTA, R: ACTCGTCATACTCCTGCTTG, 475bp; TLR4: F: CCTGTCCCTGAACCCTAT, R: AAGCATTCCC ACCTTTGT, 473bp.

The total RT-PCR reaction system was composed of $20 \mu \mathrm{L}$ in which reacted M-MLV (Moloney Murine Leukaemia Virus Reverse Transcriptase) $1 \mu \mathrm{L}, 0.1 \mathrm{M}$ DTT (dithiothreitol) $2 \mu \mathrm{L}$, dNTP (Deoxynucleotide) $(2.5 \mathrm{mM}) 4 \mu \mathrm{L}, 5 \times$ reverse transcriptase Buffer 4 $\mu \mathrm{L}$, RNA-ase inhibitor $1 \mu \mathrm{L}$, and DEPC (diethyl pyrocarbonate) water. The system conditions were $37^{\circ} \mathrm{C}$ for $60 \mathrm{~min}$, followed by $95^{\circ} \mathrm{C}$ for $5 \mathrm{~min}$ and $4^{\circ} \mathrm{C}$ for $5 \mathrm{~min}$. The PCR reaction system had a volume of $25 \mu \mathrm{L}$. It was cycled for 30 times according to the following order pre-denaturation at $95^{\circ} \mathrm{C}$ for $7 \mathrm{~min}$, denaturation at $94^{\circ} \mathrm{C}$ for $30 \mathrm{~s}$, extension at $72^{\circ} \mathrm{C}$ for $30 \mathrm{~s}$, repeated denaturation, annealing and extension, full extension at $72^{\circ} \mathrm{C}$ for
$8 \mathrm{~min}$ and at the end temperature was set at $4{ }^{\circ} \mathrm{C}$. The PCR amplified fragment was 473bp. $6 \mu \mathrm{L}$ amplified products were subjected to $2 \%$ agarose gel electrophoresis at a voltage of $80 \mathrm{~V}$ for $30 \mathrm{~min}$, and the gel imaging system was used for scanning, analysis and photographing. All the needed reagents were purchased from Invitrogen.

\section{Efficacy criteria}

The main symptoms and disease index (DAI) of the two groups of patients were quantitatively scored as previously described [14]. Colonoscopy was used to examine changes in the colonic mucosa to score according to Baron endoscopy standards [15]. The efficacy was evaluated based on symptoms combined with the endoscopic score. The typical symptoms of UC including diarrhoea, bloody purulent stool, and abdominal pain were scored before and after treatment, respectively. The incidence of localized oedema, hypotension, nausea and vomiting, dizziness and other adverse reactions in the two groups were observed and recorded.

\section{Statistical treatment}

SPSS 19.0 statistical software (IBM, USA) was used. The data was counted by $\chi 2$ test and the measurement data by T-test. A value of $\mathrm{p}<0.05$ meant the difference was considered statistically significant.

\section{Results and Discussion}

Comprehensive efficacy

It was observed that the total effective rate of the observation group was significantly higher than that of the control group after 12 weeks of treatment $(\mathrm{p}<$ 0.05) (Table I).

Table I

Comparison of comprehensive efficacy between the two groups

\begin{tabular}{cccccc}
\hline Group & Complete relief & Obvious efficacy & Effective & Ineffective & Total effective rate (\%) \\
\hline Observation group & 18 & 16 & 9 & 5 & $43(89.58)^{*}$ \\
Control group & 8 & 11 & 16 & 13 & $35(72.92)$ \\
\hline
\end{tabular}

Note: compared with the control group, ${ }^{*} \mathrm{p}<0.05$.

The score of main symptoms before and after treatment The scores of diarrhoea, bloody mucopurulent stool and abdominal pain after the treatment in the two groups were significantly decreased compared with those before treatment $(\mathrm{p}<0.05)$ (Table II). The scores in the observation group significantly decreased after treatment compared with the control group after treatment $(\mathrm{p}<0.05)$ (Table II)

Table II

Symptom scores of the two groups before and after treatment

\begin{tabular}{ccccc}
\hline Group & Time & Diarrhoea & Bloody mucopurulent stool & Abdominal pain \\
\hline Observation group & before treatment & $3.65 \pm 0.63$ & $3.21 \pm 0.72$ & $3.38 \pm 0.62$ \\
& after treatment & $0.98 \pm 0.27^{* \#}$ & $0.51 \pm 0.19^{* \#}$ & $0.31 \pm 0.41^{* \#}$ \\
Control group & before treatment & $3.30 \pm 0.91$ & $3.37 \pm 0.81$ & $3.34 \pm 0.52$ \\
& After treatment & $2.08 \pm 0.28^{*}$ & $2.13 \pm 0.35^{*}$ & $2.42 \pm 0.31^{*}$ \\
\hline
\end{tabular}

Note: compared with this group before treatment, ${ }^{*} \mathrm{p}<0.05$; compared with the control group after treatment, ${ }^{\#} \mathrm{p}<0.05$

Patient DAI and endoscopic score

The DAI and intestinal mucosal endoscopy scores of the two groups were significantly reduced after treatment $(\mathrm{p}<0.05)$. After treatment, the Baron endoscopy score of DAI of the observation group 
FARMACIA, 2021, Vol. 69, 4

was significantly lower compared with the control group $(\mathrm{p}<0.05)$ (Table III).

Table III

Comparison of DAI and endoscopic score between the two groups

\begin{tabular}{cccc}
\hline Group & Time & DAI & Baron endoscopy score \\
\hline Observation group & before treatment & $7.85 \pm 1.65$ & $2.33 \pm 0.57$ \\
& after treatment & $3.71 \pm 1.37^{* \#}$ & $0.73 \pm 0.62^{* *}$ \\
Control group & before treatment & $7.97 \pm 1.73$ & $2.38 \pm 0.49$ \\
& after treatment & $4.89 \pm 1.58^{*}$ & $1.08 \pm 0.54^{*}$ \\
\hline
\end{tabular}

Note: compared with this group before treatment, ${ }^{*} \mathrm{p}<0.05$; compared with the control group after treatment, ${ }^{\#} \mathrm{p}<0.05$

\section{Changes in serum inflammatory factors}

Before the treatment there was no statistically significant difference in serum IL-1 $\beta$, MMP-1 and TNF- $\alpha$ levels between the two groups $(p>0.05)$ (Table IV). Serum IL-1 $\beta$, MMP-1 and TNF- $\alpha$ levels after treatment in the two groups were significantly lower than that before treatment $(\mathrm{p}<0.05)($ Table IV). The treatment with CYNG determined a significant decrease in serum IL-1 $\beta$, MMP-1 and TNF- $\alpha$ levels in the observation group compared with the control group $(\mathrm{p}<0.05)$ (Table IV).

Table IV

Comparison of changes in serum inflammatory factors between the two groups $(\mu \mathrm{g} / \mathrm{L})$

\begin{tabular}{ccccc}
\hline Group & Time & IL-1 & MMP-1 & TNF- $\alpha$ \\
\hline Observation group & before treatment & $10.96 \pm 1.35$ & $2.84 \pm 0.32$ & $33.08 \pm 5.42$ \\
& after treatment & $3.57 \pm 0.83^{* \#}$ & $0.97 \pm 0.14^{* \#}$ & $15.26 \pm 3.75^{* \#}$ \\
Control group & before treatment & $10.88 \pm 1.51$ & $2.89 \pm 0.32$ & $34.17 \pm 6.09$ \\
& after treatment & $6.82 \pm 1.34 *$ & $1.71 \pm 0.27 *$ & $23.47 \pm 4.03^{*}$ \\
\hline
\end{tabular}

Note: compared with this group before treatment, ${ }^{*} \mathrm{p}<0.05$; compared with the control group after treatment, ${ }^{*} \mathrm{p}<0.05$

\section{Immune function}

Before the treatment there was no statistically significant difference in $\mathrm{CD} 3+, \mathrm{CD} 4+, \mathrm{CD} 8+$, $\mathrm{CD} 4+/ \mathrm{CD} 8+$ levels between the two groups $(\mathrm{p}>$ $0.05)$ (Table V). After the treatment, CD3+, CD4+, CD4+/CD8+ were significantly increased in the two groups compared with the levels before treatment $(\mathrm{p}<0.05)$, while CD8+ significantly decreased $(\mathrm{p}<$ 0.05) (Table V). The treatment with CYNG determined a significant increase in CD3+, CD4+, CD4+/CD8+ levels in the observation group compared with the control group ( $p<0.05)$, and no effect on the CD8+ levels $(\mathrm{p}>0.05)$ (Table V).

Comparison of immune function between the two study groups

\begin{tabular}{cccccc}
\hline Group & Time & CD3+(\%) & CD4+(\%) & CD8+(\%) & CD4+/CD8+ \\
\hline Observation group & before treatment & $51.97 \pm 5.08$ & $35.68 \pm 3.04$ & $30.76 \pm 2.18$ & $1.16 \pm 0.12$ \\
& after treatment & $63.77 \pm 4.84^{* \#}$ & $44.15 \pm 3.70^{* \#}$ & $26.44 \pm 1.87^{*}$ & $1.67 \pm 0.16^{* \#}$ \\
Control group & before treatment & $52.82 \pm 4.13$ & $35.34 \pm 2.25$ & $30.73 \pm 2.01$ & $1.15 \pm 0.14$ \\
& after treatment & $59.04 \pm 5.25^{*}$ & $38.79 \pm 2.82^{*}$ & $27.71 \pm 1.93^{*}$ & $1.40 \pm 0.13^{*}$ \\
\hline
\end{tabular}

Note: compared with this group before treatment, ${ }^{*} \mathrm{p}<0.05$; compared with the control group after treatment, ${ }^{*} \mathrm{p}<0.05$

\section{Indices of intestinal mucosal function}

Before the treatment, there was no statistically significant differences in the serum D-lactic acid and diamine oxidase (DAO) activities in the two groups. After the treatment in both groups was observed a statistically significant decrease in D- lactic acid and DAO activity compared with the levels before treatment $(\mathrm{p}<0.05)$ (Table VI). The treatment with CYNG determined a significant decrease in the serum D-lactic acid and DAO activities compared with the control group $(\mathrm{p}<0.05)$ (Table $\mathrm{VI})$.

Table VI

Comparison of the indexes of intestinal mucosal function between the two groups

\begin{tabular}{cccc}
\hline Group & Time & D- lactic acid (mmol/L) & DAO activity (U/L) \\
\hline Observation group & before treatment & $5.51 \pm 0.42$ & $7.96 \pm 1.02$ \\
& after treatment & $3.75 \pm 0.27^{*}, \#$ & $5.42 \pm 0.86^{*}$,\# \\
Control group & before treatment & $5.53 \pm 0.33$ & $7.96 \pm 0.97$ \\
& after treatment & $4.72 \pm 0.35^{*}$ & $6.69 \pm 0.85^{*}$ \\
\hline
\end{tabular}

Note: compared with this group before treatment, ${ }^{*} \mathrm{p}<0.05$; compared with the control group after treatment, ${ }^{\#} \mathrm{p}<0.05$

Expression of Toll-like receptor 4 (TLR4)

Before the treatment, there was no statistically significant differences in the TLR4 expression in the intestinal mucosa $(\mathrm{p}>0.05)$ (Figure 1). Both treatments inhibit the TLR4 in the intestinal mucosa, 


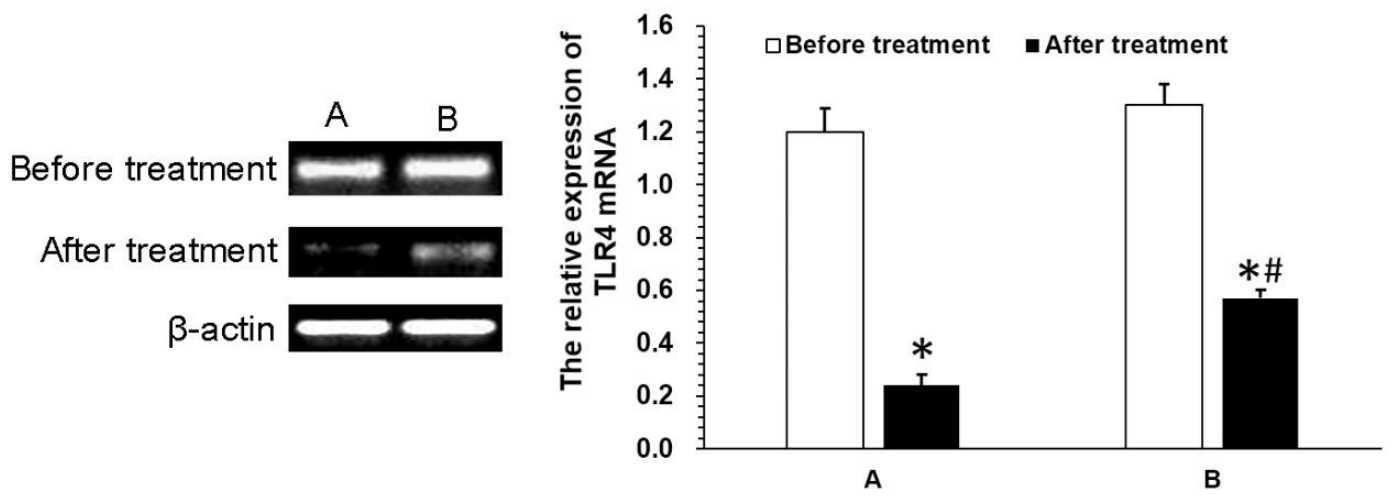

Figure 1.

PT-PCR gel electrophoresis results of TLR4. A: observation group; B: control group (compared with this group before treatment), ${ }^{*} \mathrm{p}<0.05$; compared with the control group after treatment, ${ }^{*} \mathrm{p}<0.05$.

\section{Adverse reactions}

In the observation group, there was 1 case with localized oedema, 2 cases with nausea and vomiting, and 1 case with hypotension, and the incidence of adverse reactions was $8.33 \%$ (4/48); in the control group, there was 1 case with localized oedema, 1 case with dizziness, 1 case with nausea and vomiting. The adverse reaction rate was $6.25 \%$ (3/48), and there was no statistically significant difference between the groups ( $p>0.05$ ).

In modern medicine, it is believed that the onset of UC may be related to the disorder of local immune regulation in the intestinal mucosal tissue, intestinal infection, and impaired intestinal mucosal barrier protection [16]. Modern pharmacological studies have shown that CYNG has antidiarrheal and antiulcer effects, and has obvious inhibitory effects on a variety of bacteria. It can eliminate inflammation and intestinal wall oedema, and protect gastrointestinal mucosa [17]. The specific pathogenesis of UC has not yet been fully elucidated, and it is believed that an abnormal immune-inflammatory response is involved in its onset and development [18]. IL-1 $\beta$ and TNF- $\alpha$ are both important pro-inflammatory cytokines, and they play an important role in the onset and development of UC during the active phase. They can stimulate the chemotaxis and aggregation of neutrophils in the intestinal epithelial cells to aggravate the intestinal mucosal damage [19, 20]. Increased expression of MMP-1 can aggravate the degree of intestinal mucosal tissue damage, and it is a sensitive index reflecting the severity of the disease [21]. The results of this study indicate that CYNG combined with Kuiyangling enema can reduce inflammation.

It is pointed out that in some studies the onset of UC during the active period is related to the body's immunity [22]. Changes in the number and ratio of $\mathrm{T}$ lymphocytes subsets can reflect the body's cellular immune function [23]. T lymphocytes in patients with UC during the active period are mainly manifested as the imbalance of subsets under antigen stimulation, leading to the abnormalities of other inflammatory mediators, cytokines and inflammatory cells, thus causing intestinal mucosal inflammation and tissue damage $[24,25]$. The results of this study indicate that the combination of CYNG combined with Kuiyangling enema can improve the immune function of patients.

TLR4 is the first mammalian TLR discovered. It is a transmembrane receptor in the innate immune system [26], which is expressed in many immune and non-immune cells: such as T lymphocytes, B lymphocytes, and intestinal epithelial cells [ 27 , 28]. In recent years, with the in-depth study of cellular immunology, the role of TLR4 in the onset and development of diseases has gained more and more attention. The expression of TLR4 in the intestine of normal healthy people is very small, and it is not reactive to lipopolysaccharide (LPS). However, in the intestinal tissue of patients with UC, TLR4 expression increases significantly [29, 30]. Studies showed that TLR4 expression is low in the normal colonic mucosa, but it is abnormally high in the colonic mucosa of UC, indicating that the TLR4-mediated signal transduction pathway is closely related to the onset of UC $[31,32]$.

The latest studies show that TLR4 can activate NF$\mathrm{kB}$ and inflammatory factor transcription, which leads to the activation of NF-kB, causing the expression of inflammatory factors such as TNF- $\alpha$, which constitutes a cytokine pathway related to the onset of UC [33, 34]. The results of this study show that after treatment, the level of TLR4 was significantly reduced $(\mathrm{p}<0.05)$ in both groups with higher efficacy when using CYNG. The results proved that the expression of TLR4 in patients with UC before treatment is significantly higher than 
FARMACIA, 2021, Vol. 69, 4

that after treatment, indicating that TLR4 is involved in the onset of UC. Moreover, CYNG can effectively inhibit the expression of TLR4, thereby blocking the signal pathway mediated by TLR4, reducing the release of inflammatory cytokines, and exerting its regulatory effect on cytokines, to achieve the purpose of alleviating inflammation and treating diseases.

In addition, the results also showed that the serum D-lactic acid and DAO activities of the observation group are lower than those of the control group, suggesting that the combined treatment of CYNG and Kuiyangling enema for patients with UC can help patients recover intestinal mucosal function and improve efficacy. Furthermore, it is found that the incidence of adverse reactions in the two groups is lower and the observation group had a higher treatment efficiency than the control group. Thus, the treatment based on Kuiyangling enema with CYNG has high safety and can improve the patients' quality of life.

\section{Conclusions}

The combination of CYNG and Kuiyangling enema has obvious efficacy on patients with UC, which can reduce the degree of intestinal mucosal lesions, inhibit the expression of TLR4, reduce the inflammatory response, promote the recovery of intestinal mucosal function, improve the immune function of patients, and improve their quality of life and has important clinical significance.

\section{Conflict of interest}

The authors declare no conflict of interest.

\section{References}

1. Magro F, Gionchetti P, Eliakim R, Ardizzone S, Armuzzi A, Barreiro-de Acosta M, Burisch J, Gecse KB, Hart AL, Hindryckx P, Langner C, Limdi JK, Pellino G, Zagórowicz E, Raine T, Harbord M, Rieder F; European Crohn's and Colitis Organisation [ECCO], Third European Evidence-based Consensus on Diagnosis and Management of Ulcerative Colitis. Part 1: Definitions, Diagnosis, Extra-intestinal Manifestations, Pregnancy, Cancer Surveillance, Surgery, and Ileo-anal Pouch Disorders. J Crohns Colitis, 2017; 11(6): 649-670.

2. Bergmann MM, Hernandez V, Bernigau W, Boeing H, Chan SS, Luben R, Khaw KT, van Schaik F, Oldenburg B, Bueno-de-Mesquita B, Overvad K, Palli D, Masala G, Carbonnel F, Boutron-Ruault MC, Olsen A, Tjonneland A, Kaaks R, Katzke V, Riboli E, Hart AR, No association of alcohol use and the risk of ulcerative colitis or Crohn's disease: data from a European Prospective cohort study (EPIC). Eur J Clin Nutr., 2017; 71(4): 566.
3. Qi Q, Liu YN, Jin XM, Zhang LS, Wang C, Bao $\mathrm{CH}$, Liu HR, Wu HG, Wang XM. Moxibustion treatment modulates the gut microbiota and immune function in a dextran sulphate sodiuminduced colitis rat model. World J Gastroenterol., 2018; 24(28):3130-3144.

4. Huang I, Sato Y, Sakamoto M, Ohkuma M, Ohnuma S, Naitoh T, Shibata C, Horii A, Nishimura J, Kitazawa H, Saito T, Diversity of Microflora in Colonic Mucus from Severe Ulcerative Colitis Patients Analyzed by Terminal Restriction Fragment Length Polymorphism and Clone Libraries of Bacterial 16S rRNA Gene Sequences. Advances in Microbiology, 2014; 4(13): 857-870.

5. Patrick C, Wang GS, Lefebvre DE, Crookshank JA, Sonier B, Eberhard C, Mojibian M, Kennedy CR, Brooks SP, Kalmokoff ML, Maglio M, Troncone R, Poussier P, Scott FW, Promotion of autoimmune diabetes by cereal diet in the presence or absence of microbes associated with gut immune activation, regulatory imbalance, and altered cathelicidin antimicrobial Peptide. Diabetes, 2013; 62(6): 20362047.

6. Li H, Fan C, Feng C, Wu Y, Lu H, He P, Yang X, Zhu F, Qi Q, Gao Y, Zuo J, Tang W, Inhibition of phosphodiesterase-4 attenuates murine ulcerative colitis through interference with mucosal immunity. Br J Pharmacol., 2019; 176(13): 22092226.

7. Xu CT, Meng SY, Pan BR, Drug therapy for ulcerative colitis. World J Gastroenterol., 2004; 10(16): 2311-2317.

8. Mundugaru R, Udaykumar P, Kumar KNS, Nayak S, Jacob T, Alfarhan AH, Rajakrishnan R, Protective effect of Garcinia pedunculata fruit rind in acetic acid induced ulcerative colitis. Farmacia, 2019; 67(1): 160-166

9. Scheau C, Caruntu C, Badarau IA, Scheau AE, Docea AO, Calina D, Caruntu A, Cannabinoids and Inflammations of the Gut-Lung-Skin Barrier. $J$ Pers Med., 2021; 11(6): 494: 1-26.

10. Salehi B, Shivaprasad Shetty M, V Anil Kumar N, Živković J, Calina D, Oana Docea A, EmamzadehYazdi S, Sibel Kılıç C, Goloshvili T, Nicola S, Pignata G, Sharopov F, Del Mar Contreras M, Cho WC, Martins N, Sharifi-Rad J, Veronica PlantsDrifting from Farm to Traditional Healing, Food Application, and Phytopharmacology. Molecules, 2019; 24(13): 2454: 1-35.

11. Voicu SN, Hermenean A, Olah NK, Badulescu L, Stan MS, Dinischiotu A, Designing new mother tinctures for increased antioxidant efficiency on inflammatory intestinal diseases. Farmacia, 2019; 67(2): 290-295.

12. Chen K, Lou Y, Zhu Y, Tong Xie Yao Fang: A Classic Chinese Medicine Prescription with Potential for the Treatment of Ulcerative Colitis. Evid Based Complement Alternat Med., 2021; 2021: 5548764: 1-12.

13. Chen YL, Zheng YY, Dai YC, Zhang YL, Tang $\mathrm{ZP}$, Systems pharmacology approach reveals protective mechanisms of Jian-Pi Qing-Chang 
FARMACIA, 2021, Vol. 69, 4

decoction on ulcerative colitis. World Gastroenterol., 2019; 25(21): 2603-2622.

14. Pabla BS, Schwartz DA, Assessing Severity of Disease in Patients with Ulcerative Colitis. Gastroenterol Clin North Am., 2020; 49(4): 671688.

15. Paine ER, Colonoscopic evaluation in ulcerative colitis. Gastroenterol Rep., 2014; 2(3): 161-168

16. Saito H, Hirayama A, Umemura T, Joshita S, Mukawa K, Suga T, Tanaka E, Ota M, Association between KIR-HLA combination and ulcerative colitis and Crohn's disease in a Japanese population. PLoS One, 2018; 13(4): e0195778: 1-7.

17. Jingri $X$, Ting XU, Hewei LI, Clinical efficacy of Changyuning Granule in Treating Active Ulcerative Colitis. Chinese Archives of Traditional Chinese Medicine, 2015; 1: 12-14 (available in Chinese)

18. Zhu JF, Xu Y, Zhao J, Li X, Meng X, Wang TQ, Zou BY, Zhao PY, Liu Q, Lu CL, Zheng FL, Liu HS, IL-33 Protects Mice against DSS-Induced Chronic Colitis by Increasing Both Regulatory B Cell and Regulatory $\mathrm{T}$ Cell Responses as Well as Decreasing Th17 Cell Response. J Immunol Res., 2018; 2018: 1827901: 1-13.

19. Gök İ, Uçar F, Ozgur O, Inflammatory cytokine gene polymorphism profiles in Turkish patients with ulcerative colitis. Med Glas (Zenica), 2015; 12(1): 33-39.

20. Yao P, Tan F, Gao H, Wang L, Yang T, Cheng Y, Effects of probiotics on Toll-like receptor expression in ulcerative colitis rats induced by 2,4,6-trinitro-benzene sulfonic acid. Mol Med Rep., 2017; 15(4): 1973-1980.

21. Wang ZY, Increased Expression of Matrix Metalloproteinase- 1 and 3 in Remission Patients of Steroid-Dependent Ulcerative Colitis. Gastroenterology Res., 2010; 3(3): 120-124.

22. Xu YW, Xing RX, Zhang WH, Li L, Wu Y, Hu J, Wang C, Luo QL, Shen JL, Chen X, Toxoplasma ROP16I/III ameliorated inflammatory bowel diseases via inducing M2 phenotype of macrophages. World J Gastroenterol., 2019; 25(45): 6634-6652.

23. Postovalova EA, Khochansky DN, Zolotova NA , Gao Y, Makarova OV, Dobrynina MT, Morphological Changes in Mesenteric Lymph Nodes and Lymphocyte Subpopulation Composition in Experimental Ulcerative Colitis. Bull Exp Biol Med., 2016; 160(6): 835-839.

24. Roig J, Saiz ML, Galiano A, Trelis M, Cantalapiedra F, Monteagudo C, Giner E, Giner RM, Recio MC, Bernal D, Sánchez-Madrid F, Marcilla A, Extracellular Vesicles From the Helminth Fasciola hepatica Prevent DSS-Induced
Acute Ulcerative Colitis in a T-Lymphocyte Independent Mode. Front Microbiol., 2018; 9: 1036: 1-13.

25. Slevin SM, Garner LC, Lahiff C, Tan M, Wang LM, Ferry H, Greenaway B, Lynch K, Geremia A, Hughes S, Leavens K, Krull D, Marks DJB, Nevin K, Page K, Srinivasan N, Tarzi R, Klenerman P, Travis S, Arancibia-Cárcamo CV, Keshav S, Lymphocyte Activation Gene (LAG)-3 Is Associated With Mucosal Inflammation and Disease Activity in Ulcerative Colitis. J Crohns Colitis, 2020; 14(10): 1446-1461.

26. Toiyama Y, Araki T, Yoshiyama S, Hiro J, Miki C, Kusunoki M, The expression patterns of Toll-like receptors in the ileal pouch mucosa of postoperative ulcerative colitis patients. Surg Today, 2006; 36(3): 287-290.

27. Mohammadi M, Zahedi MJ, Nikpoor AR, Baneshi MR, Hayatbakhsh MM. Interleukin-17 serum levels and TLR4 polymorphisms in ulcerative colitis. Iran J Immunol., 2013; 10(2): 83-92.

28. Szumilas D, Krysiak R, Okopień B, [The role of TLR4 receptor in development of inflammation and carcinogenesis in ulcerative colitis and pharmacotherapy of this disorder]. Wiad Lek, 2013; 66(1): 3-9.

29. Rahman FZ, Smith AM, Hayee B, Marks DJ, Bloom SL, Segal AW, Delayed resolution of acute inflammation in ulcerative colitis is associated with elevated cytokine release downstream of TLR4. PLoS One, 2010; 5(3): e9891: 1-11.

30. Meena NK, Verma R, Verma N, Ahuja V, Paul J, TLR4 D299G polymorphism modulates cytokine expression in ulcerative colitis. $J$ Clin Gastroenterol, 2013; 47(9): 773-80.

31. Tan Y, Zou KF, Qian W, Chen S, Hou XH, Expression and implication of toll-like receptors TLR2, TLR4 and TLR9 in colonic mucosa of patients with ulcerative colitis. J Huazhong Univ Sci Technolog Med Sci., 2014; 34(5): 785-790.

32. Guo QS, Xia B, Jiang Y, Morré SA, Cheng L, Li J, Crusius JB, Peña AS, Polymorphisms of CD14 gene and TLR4 gene are not associated with ulcerative colitis in Chinese patients. Postgrad Med J., 2005; 81(958): 526-529.

33. Bing X, Xuelei L, Wanwei D, Linlang L, Keyan C. EGCG Maintains Th1/Th2 Balance and Mitigates Ulcerative Colitis Induced by Dextran Sulfate Sodium through TLR4/MyD88/NF-кB Signaling Pathway in Rats. Can J Gastroenterol Hepatol., 2017; 2017: 3057268: 1-10.

34. Lin X, Liu J, TLR4/MyD88/NF-кB Signaling Pathway and Ulcerative Colitis. Chinese Journal of Gastroenterology, 2013; 18(4): 244-246 (available in Chinese). 